\title{
Perceptions and Application of the Ecosystem Services Approach among Pacific Northwest National Forest Managers
}

\author{
Stephen ES Crook ${ }^{1,2,3, *}$, Arielle Levine ${ }^{2}(1)$ and David Lopez-Carr ${ }^{3}$ \\ 1 Department of Earth, Space, and Environmental Sciences, Palomar College, San Marcos, CA 92069, USA \\ 2 Department of Geography, San Diego State University, San Diego, CA 92182, USA; alevine@sdsu.edu \\ 3 Department of Geography, University of California-Santa Barbara, Santa Barbara, CA 93106, USA; \\ davidlopezcarr@ucsb.edu \\ * Correspondence: scrook@palomar.edu
}

Citation: Crook, S.E.; Levine, A.; Lopez-Carr, D. Perceptions and Application of the Ecosystem Services Approach among Pacific Northwest National Forest Managers.

Sustainability 2021, 13, 1259.

https://doi.org/10.3390/su13031259

Academic Editor: Carlos Sanz-Lazaro Received: 29 October 2020

Accepted: 18 January 2021

Published: 26 January 2021

Publisher's Note: MDPI stays neutral with regard to jurisdictional claims in published maps and institutional affiliations.

Copyright: (c) 2021 by the authors. Licensee MDPI, Basel, Switzerland. This article is an open access article distributed under the terms and conditions of the Creative Commons Attribution (CC BY) license (https:// creativecommons.org/licenses/by/ $4.0 /)$.

\begin{abstract}
The ecosystem services concept has emerged as a guiding principle in natural resource management over the past two decades, and an ecosystem services approach to management is currently mandated as a core element of United States National Forest planning. However, the concept of ecosystem services has been interpreted and operationalized in a variety of ways, leaving a pronounced knowledge gap regarding how it is understood and implemented in different contexts. To better understand the conceptualization and implementation of the concept within United States National Forests, semi-structured interviews with planners and managers of the Pacific Northwest Region were conducted at the region, forest, and ranger district levels, addressing the following topics: (1) how has the ecosystem services concept been perceived by managers and planners?; (2) what are the perceived key ecosystem services offered by National Forest lands?; (3) how has the concept been applied at multiple spatial scales?; and (4) what are perceived challenges or opportunities related to applying the concept in the National Forest context? Results indicate that although participants had a high level of understanding of the ecosystem services concept, there was not a clear, widely adopted approach to considering ecosystem services in management. Through qualitative analysis, three general perspectives arose: one employed the concept to fulfill regulatory requirements at the National Forest scale, a second engaged with ecosystem services to improve participatory planning at the project scale, and a third, business as usual perspective, considered ecosystem services as new language for describing longstanding National Forest priorities. These results draw attention to the challenges of implementing an ecosystem services-based approach in the United States National Forest context and the continued need for the development of management-relevant methods for describing and quantifying ecosystem services.
\end{abstract}

Keywords: ecosystem services-based management; U.S. National Forest management; perceptions of ecosystem services; forest planning

\section{Introduction}

The ecosystem services concept, typically defined as the idea that functioning ecosystems provide humans with benefits that improve well-being, has become a guiding principle in global natural resource management [1,2]. The integration of the concept into United States National Forest planning was mandated in 2012 through the release of a new planning rule, which guides the preparation of new forest plans in the future $[3,4]$. Currently, the Forest Service is in the exploratory phase of considering how to integrate the concept into the planning and management of the 193 million acres of Forest Service land, and the implications of this shift in focus are unclear due to the wide range of interpretations about how to apply the concept on the ground $[5,6]$. There is a noted gap in understanding how actors obligated to apply ecosystem service approaches understand and perceive the concept, how ecosystem service approaches have been applied on the ground, and 
how knowledge regarding ecosystem services is integrated into natural resource-related decision making [7-9].

The concept of ecosystem services has been interpreted and applied in a wide variety of ways since its emergence [5]. Early on, it was employed as a metaphor for the reliance of human well-being on functioning ecosystems, thereby communicating the importance of nature to society $[10,11]$. Many studies following this line of reasoning have focused on valuing aspects of a particular natural resource, or the sum total economic value of multiple resources at a given spatial scale [2]. The metaphor that ecosystems provide benefits that have economic value evolved into the development of payment for ecosystem services (PES) programs, wherein those benefitting from ecosystem services provide monetary compensation to those providing services and benefits [12-14]. PES programs often focus on compensation for and prioritization of the provision of one or a few ecosystem services rather than considering tradeoffs, synergies, or aggregate provisioning of multiple services [15].

More recently, academic and policy spheres have focused on using the ecosystem services concept to make more informed decisions in natural resource planning through considering tradeoffs and synergies among ecosystem service types under different land management scenarios [16-18]. This approach requires identification of the ecosystem service categories to be considered, mapping of landcover types and linking these with associated ecosystem services, understanding of ecosystem service preferences and values, and quantification of aggregate values at specific planning scales [18,19]. Despite widespread conceptual development in the use of ecosystem services for natural resources planning and management, there are still few examples of effectively accomplishing this on the ground $[10,20,21]$.

These competing interpretations of how the ecosystem services concept might be applied has led to challenges in application [22,23], as to date "there is no clear consensus on how exactly ecosystem services should be defined and classified ... and further interpretations might emerge" (Martin-Ortega [5] (p. 8)). At least eleven different ecosystem service frameworks, each with its own definition and classification system, have been developed, leading to a lack of clarity as to what constitutes an ecosystem service that should be considered in analysis [23]. There is further confusion about what managing for ecosystem services means. As noted above, the ecosystem services concept has been employed to address a wide range of potential goals using a variety of tools, with little consistency [19].

Inconsistent definitions and a lack of conceptual clarity have hindered the adoption and application of the concept in planning and management $[19,22]$. In some cases, its application has resulted in a "fake consensus", where different stakeholders agree on an approach for which they have different underlying understandings and interpretations [5]. It can also result in "business-as-usual" management, where new terminology and discourse are used to justify continuation of longstanding actions [5]. Furthermore, there has been a recognition that political conflicts between ecosystem service priorities among stakeholders remain despite the unifying language of an ecosystem services approach [6].

In an attempt to establish a common baseline understanding of what constitutes an ecosystem services approach, Martin-Ortega et al. [5] (p. 8) stated that such an approach is "not a management tool per se, but rather a pair of glasses that one might wear to tackle the problem at hand." With a goal of clarifying the ambiguity of the concept, they identified four nested components of what makes up an ecosystem services-based approach. First, there is a focus on anthropocentric instrumentalism, in which the human-nature relationship is defined as revolving around "the benefits humans obtain from nature" [5] (p. 8). Second, these approaches consider the core output of ecosystem functioning to be service delivery, rather than traditional ecological outputs (biogeochemical cycles, energy flows, etc.). Third, an ecosystem services approach relies on the integration of interdisciplinary scientific knowledge along with local knowledge and preferences in the creation of models for tradeoffs. Finally, such an approach includes the assessment of a variety of services (either 
through qualitative or quantitative valuation) so that changes to these values in different scenarios can be incorporated into the decision-making process [5].

As Hummel et al. [24] (p.2) contended, "a mismatch between academic and management perceptions of ecosystem services and management priorities may well result in important shortcomings for the application of research outputs in adaptive protected area management." While a few scholars have recently investigated knowledge uptake upon direct application of the type of ecosystem services approach outlined in the previous paragraph $[6,17,25]$, there is limited research into the awareness, perception, and understanding of ecosystem services approaches among planners and managers who are ultimately tasked with applying the concept $[7,8,21,22,26-28]$. These studies have noted the challenge in translating academic and theoretical tools to on-the-ground management and the importance of understanding practitioner perceptions to the implementation process [7].

\subsection{The Ecosystem Services Approach in United States National Forest Management}

Investigating the current understanding and application of ecosystem services among decision-makers is important in the context of United States National Forests because the concept has recently become the latest in a series of dominant approaches to management embraced by the U.S. Forest Service [3]. Prior to the 1960s, management of National Forests was characterized by the dominant-use era, focused primarily on sustained timber yield. That gave way to what is known as the multiple-use era, where the Forest Service (FS) focus was on balancing resource extraction with encouraging ecosystem health and recreation [29]. The ecosystem management era of the 1990s and early 2000s focused on furthering the goal of including multiple uses, yet witnessed continued tension between the conflicting goals of resource extraction and the improvement of ecological conditions [3].

The transition to ecosystem services-based management within the Forest Service began following the Millennium Ecosystem Assessment [3,30,31]. The perceived potential benefits of focusing management on an ecosystem services approach include better communication of the benefits National Forest lands provide to society, the potential ability to expand accounting of forest benefits beyond those that are currently quantified, and the establishment of payment for ecosystem service partnerships with public and private bodies $[3,31]$. Because of the promise of these applications, the idea of ecosystem services was included as one of the key principles of the 2012 Planning Rule, which guides the development of individual forest plans into the future. The text of the 2012 Planning Rule states that, upon plan revision, individual forest plans must "provide for multiple uses and ecosystem services, considering a full range of resources, uses, and benefits relevant to a unit" [4].

A wide variety of pilot studies and projects have demonstrated how ecosystem services might be brought into National Forest planning. These can be categorized into two general groups: studies that establish or refine how an ecosystem service approach can be integrated into National Forest management [3,31-33] and studies that demonstrate how one or more service could be measured, modeled, or valued [34,35]. However, as previously noted, there is little understanding of how guiding frameworks and methods for ecosystem service assessment have been applied on the ground and have influenced decision making $[6,17,36]$.

\subsection{Research Goals}

In this article, we investigate current perceptions of ecosystem services and experiences with employing ecosystem services approaches within the Pacific Northwest Region of the U.S. Forest Service. While National Forest lands implicitly provide a wide array of ecosystem services to local communities and society, it is unclear what forest managers think it means to manage for specific ecosystem services or which perceived key services should be prioritized in management. Our aim is to investigate the current application of the ecosystem services concept in a specific context, Pacific Northwest National Forests, to provide information that can better inform its institutional application. In doing so, we gain insight into the different ways that current actors in implementation understand the concept of ecosystem services and the obstacles to implementation. At the same time, we 
shed light onto the perceived challenges and opportunities associated with this shift in focus according to National Forest planners and managers.

To achieve these goals, we address the following research questions:

- How is the ecosystem services concept understood by Forest Service planners and managers in the Pacific Northwest?

- What do Pacific Northwest National Forest planners and managers perceive as the key ecosystem services that National Forest lands offer society?

- In what ways has the ecosystem services concept been applied in Pacific Northwest National Forest management?

- What are perceived challenges and/or opportunities in applying the concept?

\section{Materials and Methods}

\subsection{Study Area}

Three National Forests out of the seventeen in the Pacific Northwest Region were selected for this initial assessment: the Deschutes and Fremont-Winema National Forests in Oregon and the Gifford Pinchot National Forest in Washington (Figure 1). These forests were selected primarily because they were determined to have different biophysical and socioeconomic contexts and differing levels of exposure to the ecosystem services concept based on initial review and informal interviews. Specifically, they offer management perspectives from forests on both the west side and east side of the Cascade Range, resulting in areas that have different rainfall patterns, fire patterns, and vegetation types. They are also areas that attract a diverse array of user groups, from predominantly urban recreational users to nearby rural communities that depend on National Forest lands for their livelihoods.

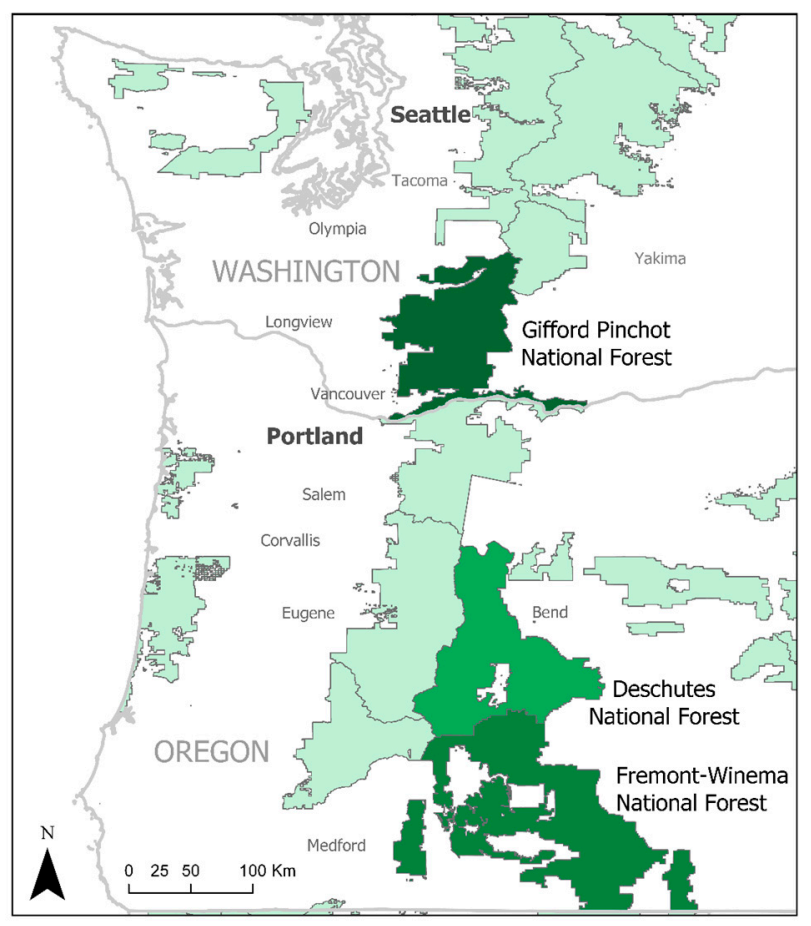

Figure 1. Map of the National Forests included in this study.

Gifford Pinchot National Forest (1.4 million acres) is the southernmost National Forest of the Washington Cascades, stretching from just south of Mount Rainier to the Columbia Gorge [37]. Included within these boundaries are Washington's second-highest peak, Mount Adams, as well as the Mount St. Helens National Volcanic Monument. While the forest is easily accessed from the Portland-Vancouver metropolitan area, it is generally still considered a mixed urban-rural forest, with several local communities that 
have traditionally depended on forest lands for their livelihoods, while being ranked 7th regionally in recreation visits [38]. The Gifford Pinchot is near the Pacific Northwest Regional Office, and preliminary interviews indicated that it is in the early stages of considering ecosystem services concepts.

Deschutes National Forest (1.6 million acres) is located in Central Oregon, stretching from the crest of the Cascades toward the semi-arid steppes of Eastern Oregon [39]. It is located adjacent to Bend, Oregon, an outdoor sports hub and a major source of recreation visitors, and includes Mt. Bachelor, one of the most popular ski areas in the Pacific Northwest. Together, these things make it the third most visited forest for recreation regionally after Mount Hood and Mount-Baker Snoqualmie [38]. However, despite high visitation density near Bend, substantial areas of the forest are still highly rural and are used more for dispersed recreation and forestry activities. The forest was selected for this study due both to its unique spatial context and to its recognition as an early adopter of the ecosystem services concept within the Forest Service [34,40].

Fremont-Winema National Forest (2.3 million acres) was administratively formed in 2002 upon the merger of the Fremont National Forest and the Winema National Forest [41]. It is located in Southern Oregon, and like the Deschutes stretches from the forest-covered crest of the Cascades to the semi-arid steppes to the East. Far from any major urban areas (the largest city within an hour of the forest is Klamath Falls, population 21,524), the forest has a continued focus on supporting local communities through resource extraction and recreational opportunities in areas that still allow for solitude: "where the self-reliant recreationist has the opportunity to discover nature in a rustic environment" [41]. As of the most recent estimate, it ranked second to last in the region in the number of recreation visits [38]. Additionally, a large portion of the forest is under a unique co-management arrangement with the Klamath Tribes [42]. Fremont-Winema National Forest is physically distant from the regional office, and there was little evidence in Forest Service documents and initial interviews that ecosystem services concepts are being applied in the management of this forest.

\subsection{Semi-Structured Interview Protocol}

Semi-structured interviews were conducted with United States National Forest planners and managers in the Pacific Northwest region to address the research questions outlined above. Key informants were identified and contacted through pre-existing contacts at the Forest Service and through placing direct calls and emails to select National Forest offices in the project region. In total, 12 interviews were conducted with planners and managers from the Gifford Pinchot (5), Deschutes (3), and Fremont-Winema (3) National Forests, as well as the Pacific Northwest Regional Office (1).

In addition to gaining perspectives from multiple National Forests with different spatial contexts and levels of exposure to the ecosystem services concept (described above), we sought interviews with planners and managers at different administrative levels within the Forest Service. The Forest Service's organizational structure consists of four levels: most ground-level management activities are carried out at over 500 ranger districts staffed by 10-100 people, from technicians to the supervisory district ranger; each of the 154 National Forests, made up of several ranger districts, has a centralized supervisor's office; 9 Regions coordinate activity among multiple National Forests; finally, there is a National Headquarters in Washington D.C. [43]. Interviews here were made up of participants at the Region (1), National Forest (4), sub-forest (multiple ranger districts) (2), and ranger district (5) levels. All the interviews were conducted in-person between August 2017 and May 2018.

The semi-structured interview protocol included a list of 12 questions that were designed to elicit further, in-depth discussion and questioning related to the research questions outlined above. The themes explored during discussion included the participant's understanding of the ecosystem services concept, their experiences implementing the concept, their perceptions of how the concept has been implemented within the Forest Service, the key ecosystem services provided by the National Forest in which they work, 
pressing management challenges, and stakeholder groups related to the forest. Interviews lasted from 36 to 111 minutes, with a median time of 54 minutes. Interviews were digitally recorded and transcribed for review. NVivo was used to conduct coding based on themes that arose in the data. Institutional Review Board human subjects research approval was granted for the research protocol by San Diego State University (approval number HS2017-0137), and participants were informed that confidentially and anonymity would be maintained.

\section{Results}

Although respondents stated that they were familiar with the concept of ecosystem services, they differed in their perceptions of what it meant to use an ecosystem service approach for management. Although respondents perceived a wide range of key services, cultural services were most frequently identified as the most important services offered by National Forest lands. Provisioning services in general, and timber production in particular, were perceived as ecosystem service priorities by most. The following sections elaborate in more detail the key findings in relation to participants' understanding of ecosystem services, perceptions of key forest ecosystem services, use of ecosystem services as a planning approach, and identification of opportunities and challenges in applying the concept.

\subsection{Understanding of the Ecosystem Services Concept}

When asked how they might expand or modify the definition of ecosystem services as "the benefits people obtain from ecosystems," most people interviewed saw that definition as suitable and comprehensive. Several expanded upon the definition by pointing out specific ecosystem services or categories (e.g., "drinking water, cultural, spiritual, etcetera"). Some respondents thought it was important to distinguish between economic and noneconomic benefits: "I see ecosystem services more as things that are more non-commercial that the forest provides ... though I think that timber and agriculture are benefits to humans, I think ecosystem services are more of those less marketable aspects." Others, however, considered both economic and non-economic benefits as ecosystem services, stating, for example: "I think [the term] benefits is fine, economic or otherwise." Some specifically wanted to clarify that it is how people relate to or feel about the land or landscapes, rather than just how they benefit from it.

As in other studies, participants noted challenges with ecosystem services terminology and classification $[6,7,27,44]$. Those who had experience implementing individual projects that integrated an ecosystem services approach decided to "strip away" ecosystem services categories, such as "provisioning", "regulating", "cultural", and "supporting", which they did not find valuable in talking with the public. For those working at the project scale, presenting these categories was not "helpful in getting [the public] to talk about what they care about." Lack of definitional clarity among planners and managers was apparent, as participants did not always associate things that were previous Forest Service priorities, particularly those with a primarily economic value, as being ecosystem services. Following the discussion of priority ecosystem services, one participant was asked a followup question about how they thought timber fit into the ecosystem services framework: "I was thinking everything but timber as ecosystem services. Absolutely timber is still ... it's our largest commodity."

\subsection{Perceptions of Key Ecosystem Services for National Forest Management}

Participants considered a wide range of ecosystem service types to be the most important offered by National Forests lands, although most responses fell into two categories. First, many of the perceived key services were those that had direct human benefits, including cultural services, provisioning services related to timber and forest products, and the direct economic impacts forest industries have on communities (Table 1). All but two respondents listed recreation among the most important services provided, with many specifying more detailed cultural services including aesthetics, cultural heritage, spiritual- 
ity, and solitude. Eight discussed provisioning services including special forest products like huckleberries, firewood, and mushrooms. Others discussed the cultural aspects of these provisioning services, stressing the importance of the harvest of certain plant and animal species to local tribes and communities. Likewise, although timber is generally considered a provisioning service, it was usually mentioned as a key ecosystem service in the context of the economic benefit it provides to local communities and its central place in the livelihoods of local individuals.

Table 1. Number of respondents who discussed categories as key ecosystem services provided by National Forest lands and key ecosystem services for management.

\begin{tabular}{lcc}
\hline Ecosystem Service Category & $\begin{array}{c}\text { Key Ecosystem Services } \\
\text { Provided to Society }\end{array}$ & $\begin{array}{c}\text { Ecosystem Service Priorities } \\
\text { for Management }\end{array}$ \\
\hline Recreation & 10 & 4 \\
Non-timber forest products & 8 & 4 \\
Clean water & 7 & 1 \\
Timber & 5 & 7 \\
Fish habitat & 4 & 3 \\
Jobs/Local economy & 4 & 3 \\
Cultural heritage & 3 & 1 \\
Animal habitat & 1 & 2 \\
Hunting & 1 & 1 \\
Carbon sequestration & 1 & 0 \\
Intrinsic value & 1 & 0 \\
Clean air & 1 & 0 \\
Soil health & 1 & 0 \\
Aesthetics & 1 & 1 \\
Safety/Fire thinning & 0 & 3 \\
Research & 0 & 1 \\
User conflict management & 0 & 1 \\
\hline
\end{tabular}

The second prominent grouping included those non-timber categories that have been longstanding Forest Service priorities predating the ecosystem services-based management era. Specifically, perceived priorities included habitat and clean water for certain fish species and habitat for terrestrial endangered species. Many respondents also mentioned the importance of clean water to local communities. Overall, regulating and supporting services (other than habitat) were seldom mentioned. One participant highlighted the intrinsic value of the forest, clarifying that the forest itself provided clean air and healthy soil, which were central to providing a wide range of other benefits. Another participant mentioned carbon sequestration as one of the key services offered to society.

Participants gave fewer responses when asked about the perceived priority of ecosystem services for management. The largest number of respondents perceived a continued focus on timber production. They communicated that it was still the Forest Service's mandate to provide timber, and that meeting timber targets was still a central goal of on-the-ground management. In many cases, this perception was also tied to the importance of the economic impacts of timber for local communities. Other frequently mentioned priority services for management included fish and animal habitat, recreation, and special forest products. The largest discrepancy between perceived benefits that the forests provide and perceived priority ecosystem services for management included clean water, with only one respondent reporting clean water as a priority for management. No regulating services were mentioned as priorities for management. Notably, several respondents mentioned fire management and other public safety-related efforts, as well as the management of conflicts between users, as key management priorities, but these do not fit neatly into any traditional ecosystem services categories. 


\subsection{Applications and Understanding of the Ecosystem Services Concept: Three Perspectives}

The twelve interviews with National Forest planners and managers revealed three general perspectives toward the ecosystem services approach as applied to National Forest management (Table 2). The first perspective considered an ecosystem services approach as a Regulatory Requirement at the forest scale, in which ecosystem services terminology is used along with earlier Forest Service categories to describe a range of benefits the forest provides to society. The second perspective viewed the ecosystem services approach as a new method for Participatory Planning that emphasized inclusion of local stakeholder values and priorities. The third perspective was a continuation of Business as Usual, where ecosystem services concepts were considered primarily as a repackaging of longstanding Forest Service priorities while offering potential pragmatic benefits primarily within disciplinary (rather than interdisciplinary) contexts.

Table 2. Summary of the three perspectives toward ecosystem services.

\begin{tabular}{cl}
\hline Perspective toward Ecosystem Services & \multicolumn{1}{c}{ Key Features } \\
& Ecosystem services included because of, or in anticipation of, statutory requirements \\
& Forest-scale consideration of ecosystem services \\
Regulatory Requirement & Characterization of ecosystem services for Forest Plan Revision \\
& Evolving forest plan beyond timber, wildlife, and water \\
& Stakeholder outreach to investigate key services \\
& Integration of local stakeholder priorities at early stages of project planning \\
& Local project-scale consideration of ecosystem services \\
& Focus on providing what local stakeholders want \\
& Multi-objective purpose and needs statement during the National Environmental \\
& Policy Act (NEPA) process. \\
& Noted on-the-ground applications with positive outcomes \\
\hline Business as Usual & Blurred boundary between previous paradigms and ecosystem services \\
& Pragmatic adoption of certain elements of ecosystem services concepts relevant to \\
& disciplinary needs \\
& Ad hoc use of concepts rather than a unified framework \\
\hline
\end{tabular}

Note: Italics format is meant to draw attention to the names we have given to these perspectives so that they can be highlighted and better linked to the relevant sections in text below.

The Regulatory Requirement perspective considered ecosystem services as a new guiding principle for forest-level planning and plan revision. Although plan revisions have not been carried out on Pacific Northwest Forests according to the 2012 Planning Rule, some respondents reported experience in integrating the concept into forest planning in other regions. These respondents held the general perspective that integrating an ecosystem service approach meant realigning National Forest goals at the forest plan level, along with some modification in related Forest Service processes such as public outreach for plan revision. According to the draft forest plan assessment for one of the forests where participants had experience (Nez Perce Clearwater), the interdisciplinary team (IDT) worked with the public to identify key ecosystem services to include in plan revision [45]. All the services identified were narrowed down by the IDT to those that (1) were the most important to people and (2) would be affected by a new land management plan [45]. In the Assessment document, the IDT considered condition and trend, scale, connection to ecosystem type, importance to people, and the impact of management actions on a selection of ecosystem services that included clean water, clean air, wood products, forage, fish and wildlife, cultural/heritage values, aesthetics, recreation, soil stabilization and landslide protection, carbon sequestration and climate regulation, and flood control. This consideration of a wide range of objectives in the assessment process for plan revision marked a perceived departure in National Forest goals for respondents: "The old forest plans, at least in Region 6 here, were more focused around timber production and what we could get off of the forest instead of what the forests actually provide." The new focus worked "to make sure that we're 
paying attention to everything instead of just trying to get timber off [the forest]." Another participant remarked that the goal of the process was "trying to focus on what affects the people" beyond the timber, wildlife, and water services that had long been considered important for management.

Participants noted new processes that were associated with this implementation of an ecosystem services approach. Primarily, it represented a new way to gain input for a more participatory process for the Forest Plan-level Environmental Impact Statement. Participants reported doing their own research on ecosystem services in preparation for talking about the new emphasis in management with the public. At the public meetings they conducted and attended, discussion with the public was carried out using the vocabulary of ecosystem services. It was also noted that the concept had made it into the National Environmental Policy Act (NEPA) process and that Forest Plan amendments required attention to how a proposed action would affect a set of ecosystem services, even in forests that had yet to start plan revision. Overall, the Regulatory Requirement perspective views an ecosystem services approach to focus on the establishment of new methods that expand vocabulary and outreach for plan revision and amendment at the forest scale.

The Participatory Planning perspective sees an ecosystem services approach as a process that seeks to better integrate local stakeholder priorities related to a specific place into the early stages of project-level decision-making. This was the perspective generally held by those people who had experience with an ecosystem services approach conducted within the Deschutes National Forest. One participant expressed this perspective by stating "we've used ecosystem services as a way to interact with the public to determine the values that are most important to them in an area, to help us evolve a proposed action."

Respondents supportive of ecosystem services as a way to determine public values toward planning outcomes often expanded upon the generic definition of ecosystem services ("the benefits that people obtain from ecosystems") according to their experiences with local stakeholder outreach, stressing the importance of "social goods and services." While their definitions did include other ecosystem services like "clean fresh water, fresh air," many expanded upon a sense that the key innovation is the explicit attention to cultural values related to place. Respondents stated that they would add that it is "how they (people) relate to the land" and that it is really about "what [ ... ] people care about on the landscape." This view of ecosystem services stresses the benefits individuals know they want and consciously value more than those that benefit society more broadly. As an example, one respondent referred to firewood collection as a cultural ecosystem service uncovered through their outreach, where groups going together to cut firewood is an important social aspect of that place. Another expanded on these ideas:

"The services would be recreation, or spiritual benefit, or whatever ... but as the public comes and looks at the land ... how do they feel about it? That relationship can be 'I get my spiritual aspect ... 'or 'even though I'm not in the timber industry I think this land should produce timber.' It's how they feel about the National Forest."

When asked about their experiences with ecosystem services in their professional role, these respondents focused on specific examples that they considered to be employing an ecosystem services approach at the project scale. The key example many discussed, which has previously been documented in the literature, is the Big Marsh Project carried out in the Deschutes National Forest [31,40]. The ecosystem services approach applied in this project included substantial discussion about ecosystem services and values within the Forest Service district office and with members of the public, along with the use of participatory mapping and field visits for involved stakeholders. Upon collection of data on values, results were used to develop "a proposed action and to look at alternatives" for the NEPA process. At this stage, respondents noted that the process had resulted in an "atypical purpose and needs statement" for the NEPA document instead of the traditional statement that might focus on measurable outcomes for one resource area. For example, one respondent described previous projects as being guided by singular goals; stating either "we want to reduce stand density, we want to create this type of habitat, (or) we 
want to have economic value..." Meanwhile, to them, employing an ecosystem services approach "was kind of saying [they] want to do a lot of different things all at once."

Participants involved in the process stated that employing this approach resulted in different outcomes for the Big Marsh area. Through the process, the Forest Service learned that the stakeholders who were consulted preferred a semi-wilderness experience to developed recreation sites that would be more easily accessed by the wider public. Respondents stated that if they had not used an ecosystem services approach, the resulting decisions made surrounding Big Marsh would have been different, and there likely would have been more developed recreation sites including trails and campgrounds.

Participants expanded upon other examples that applied lessons learned as part of the ecosystem services approach used during the Big Marsh Project. However, multiple respondents referred to these processes conducted elsewhere as "ecosystem services light" because some of the features from the Big Marsh Project were simplified or stripped away. Put another way by one respondent, "ecosystem services light" meant that the project proceeded with "a more traditional forest service planning process" that was underpinned by the goal of making the project fit the local community's interests. The three other projects carried out using the "ecosystem services light" approach in the Deschutes National Forest consisted of more limited outreach and data collection on place-based values and priorities with both Forest Service staff and with the public.

Participants from other contexts were aware of the new approach taken in the Deschutes, stating that their perception of the Deschutes approach was that it is "a really different way to come at planning from the kind of traditional forest service perspective... You think of it differently if you're coming at it from an ecosystem services framework than if you're coming at it from a silviculture framework or just a straight ecological framework. You might just get a different perspective on it." This respondent confirmed the view that this perspective emphasizes the values stakeholders derive from the landscape: a scrappy lodgepole stand by a lake that provides shade in summer might be considered as valued by stakeholders, while resource area experts might see it as a fire hazard or as only having silvicultural value.

The Business as Usual perspective was brought forth by respondents who considered ecosystem services primarily as new language and terminology for things that the Forest Service has already been doing. Participants who discussed ecosystem services from this perspective understood the definition and terminology of ecosystem services but did not clearly consider ecosystem services as an integrative process that could be used in guiding planning and management decision-making. However, they did identify benefits to employing an ecosystem services lens largely within disciplinary contexts. This perspective often included references to past guiding principles within the Forest Service such as "multiple use management," "ecosystem management," or "integrated resource management." One respondent stated, "You know, we're a multiple use agency, we appreciate the range of benefits that are provided by the ecosystem. We manage for those. We just don't necessarily think of it as ecosystem services work all the time." Put more bluntly, "I feel like it (ecosystem services) is multiple use, just with fancy new language that people don't understand."

When respondents holding this perspective discussed management in terms of ecosystem services, they frequently referenced examples using terms and categories used in these earlier frameworks. One respondent mentioned "viewsheds", or aesthetics as an ecosystem service, in planning: "we could actually talk about so many acres of viewshed opened up or something like that... I think you could translate it easy enough ... to ecosystem service terminology. But we've had that term for a long time in our planning. We actually manage for viewsheds, [and we] used to when we were doing clearcutting-there were concerns about impacting the viewshed." Likewise, respondents with this view discussed the importance of habitat for fish and wildlife, which are resource areas more commonly associated with the ecosystem management paradigm than with ecosystem services. When asked about examples of the implementation of ecosystem services, one respondent stated, 
"I think we've always had a restoration program outside of timber. That seems to fit pretty cleanly into ecosystem services. Dam removals, road decommissioning, aquatic restoration specifically ... There's no economic benefit to those projects. There is no economic product coming off the forest... I didn't label it ecosystem services but we have been doing that sort of work since I've worked for the Forest Service."

Despite the lack of unified, process-based use of an ecosystem services approach, participants identified ways in which they had, or could, engage with ecosystem services in their work. Some respondents found it a useful framework for communicating the value of National Forest lands, saying that "it's more giving context to the public about our landscapes" and that they use it "to tell the story of the benefits that the forest provides" in forest outreach and publications. There was also reference to the role of ecosystem service quantification within the communication context: "There is an element of quantification ... to help people realize this [benefits from ecosystem services] is real. Even though they're hard to quantify there are people in this agency who are working hard to do so." They saw potential in reporting accomplishments in terms of benefits provided beyond those that traditionally have been quantified. Although two respondents noted potential benefits of quantification of a wider range of ecosystem services, they did not give specific examples of that work in any specific forest context. Overall, it was apparent that there had been a move toward expanding the type of projects undertaken and the range of goals considered in those projects, whether or not these outcomes were directly related to explicit use of the ecosystem services concept.

Outside of these three perspectives, there was limited discussion of other uses of ecosystem services approaches. One participant referred to Forest Service involvement in a payment for ecosystem services program in private and state forests surrounding National Forest lands in the region. There was also one mention of the potential for scenario planning based around ecosystem services using a spatial modeling approach. However, this discussion centered around the lack of interoperability of disciplinary Forest Service data and the fact that data are not currently used in that way.

\subsection{Opportunities and Challenges Identified by Participants}

Managers and planners holding the Participatory Planning perspective viewed the shift toward an ecosystem services approach as positive for management, with several expressing surprise that other areas were more resistant to implementing ecosystem services approaches to management. Participants saw an ecosystem services approach as a useful mechanism for improving public outreach and inviting input early on in projects, which they viewed as important. One participant stated that the ecosystem services approach is "going to be helpful ... a big part for me doing this process is just letting people tell us what they care about regardless of whether it goes into the project ... people just like being heard." Another discussed how an ecosystem services approach improves upon business as usual:

"The Forest Service is pretty good about ... here's what we should do with vegetation, here's what we should do with hydrology issues, and spotted frog issues, and fish issues, those things are pretty easy for the government to figure out. We're all specialists in those areas. We're not necessarily specialists in 'how does the public feel about a particular area?' What did they value in that particular area? How would they like to see it? To me, that's kinda how ecosystem services plays into the modification of what we would potentially have done."

Respondents with either the Regulatory Requirement or Participatory Planning perspectives, as well as experience using different ecosystem services approaches at two different planning scales (project- versus forest-level), had trouble envisioning their version of the concept at alternative scales. One adherent of the Regulatory Requirement perspective stated, "You cannot look at ecosystem services on a small project scale because the analysis would be meaningless. It wouldn't inform decision makers of alternatives ... we're going to look at ecosystem services for this trail? No, we're not!" Another participant holding 
this perspective stated, "At the 30,000 foot scale, you're really saying what you can do in those areas. At the project scale we're just managing for [timber] target..." Alternatively, adherents to the Participatory Planning perspective pointed out that the sheer magnitude of managing at the forest scale would create too much complexity in the range of values that would need to be understood and considered. At the forest scale, the "diversity of opinions, diversity of everything that you're working with becomes in my mind ... I don't know how you would get your hands around what's the right thing to do ... it's a huge thing to try to figure out ... how that works at the broader scale." They believed that the project scale was ideal for listening closely to a small group of stakeholders and best for trying to integrate their place-specific values into alternatives.

Challenges were also identified in applying this approach to a wide range of project contexts. Among adherents to the Participatory Planning perspective, there was agreement that the Big Marsh Project represented an ideal context for the application of this type of ecosystem services approach. However, some expressed doubts that the process would result in useful data, insight, or different decisions if applied in a more heavily forested area where a more traditional timber-focused project would likely take place. In such a context there would be less public interest, less recreational use, and less obvious multifunctionality in the landscape; characteristics that were perceived as necessary in soliciting sufficient stakeholder input into the project.

\section{Discussion}

Results confirm the lack of clarity surrounding both the concept of ecosystem services and what it means to apply an ecosystem services approach. While respondents broadly understood the meaning of the concept, on-the-ground application revealed an explicit emphasis on cultural ecosystem services along with a view that, while other Forest Service management foci are implicitly ecosystem services, they are not considered a central part of employing an ecosystem services approach [7]. Each of the perspectives outlined above contains at least some of the four core elements of an ecosystem service approach as defined by Martin-Ortega et al. [5], although to differing degrees. As their first element outlines, there has clearly been a shift in using ecosystem services language, and all participants were familiar with the concept. The second element, in which the core outputs of ecosystem functioning were considered to be service delivery, was present at the project scale, but not necessarily as a comprehensive guiding principle for respondents who viewed ecosystem services as a supplementary approach to other necessary Forest Service approaches. There was strong adherence to element three, integration of transdisciplinary scientific and local knowledge and preferences, as two of the three (Participatory Planning and Regulatory Requirement) perspectives centered around explicit integration of local values as part of the ecosystem services process. The fourth element, an emphasis on quantitative or qualitative assessment of ecosystem service values delivered by ecosystems, was demonstrable only through limited qualitative assessment: increases or decreases in the provision of prioritized ecosystem services qualitatively described in the Big Marsh Project [40]. Additionally, few participants referenced potential future use of monetary quantification or ecosystem services modeling.

While the approaches used are largely based on the core conceptual elements underpinning an ecosystem services approach, they diverged from methodologies and framing commonly employed in the academic literature. For example, only one of the participants discussed the use of quantitative spatial modeling of multiple ecosystem services in order to consider tradeoffs and synergies among alternative land-use options according to different scenarios - methodologies frequently associated with using ecosystem services in spatial planning $[16,18,25,26]$. Similarly, there was little consideration of the use of the concept to explicitly communicate the value of National Forest lands to society through the calculation of the economic value of one or more resources. Nor was there discussion of the potential for the establishment of payment for ecosystem services programs $[2,15,46]$. This disconnect between the understanding of ecosystem services methodologies in the research 
community and among the management community is likely related to both the difficulty in adapting such methodologies to different spatial scales, policy settings, and land-use settings [27], as well as the fact that these methodologies are simply not yet mandated as part of on-the-ground management, and therefore not among the day to day priorities of managers.

Participants discussed the degree to which the Forest Service had substantial data and models related to individual forest resource areas, although in only one case were these data described as potentially informing ecosystem services tradeoff modeling. There are opportunities for connecting tools that have been developed for the quantification of ecosystem services in the academic literature to the quantification of National Forest ecosystem services. This could include the exploration of new integrative modeling frameworks or the application of ecosystem service modeling solutions like ARIES and InVEST to Forest Service data $[18,20,47,48]$. This would require transdisciplinary collaboration among Forest Service scientists working within narrow disciplinary areas, as well as the acceptance that early stages of integrated modeling necessarily include high levels of uncertainty when compared to highly developed single-resource models.

Overall, it is apparent that in the Pacific Northwest region, the concept of ecosystem services has been employed primarily as a way to implement forms of participatory planning at multiple levels. Through their outreach efforts focused on understanding the values of interested groups, adherents to both the Regulatory Requirement and Participatory Planning perspectives prioritized local stakeholder uses and values over more distant stakeholders and societal interests. Multiple respondents holding the Participatory Planning perspective stated that in some cases they deferred to local stakeholder values and appeals to not develop recreation sites and trails that might have been developed otherwise, serving the interests of local constituencies in limiting access to outsider groups. The recreation sites that were not developed may have held greater value to more distant stakeholders who were not consulted in the outreach used in this version of an ecosystem services approach.

Participatory planning and stakeholder outreach within ecosystem services processes has long been called for to promote successful application of ecosystem services-based management $[49,50]$. This focus, however, brings up important questions about who is included and excluded in the process. While National Forests are made up of places that hold special meaning to local residents, as federally managed forests, they also explicitly serve larger regional and national constituencies [34]. Employing multiple methods to qualitatively and quantitatively assess ecosystem services could better include these broader constituencies: web-based ecosystem service values mapping has been explored to include stakeholder values at the regional scale $[35,51]$, and integrative modeling exercises (introduced above) may better integrate ecosystem services that are valuable over larger scales (e.g., carbon sequestration). We need methods to integrate and balance the ecosystem services that are valued by individuals at multiple scales, as well as those that have societal value more broadly.

Another hurdle to applying an ecosystem services approach is that some viewed it as an added burden to already stressed budgets and workflows that have been developed to address other priorities rather than as a potential way to address those challenges. Respondents were unclear about how an ecosystem services approach might be used to address what they perceived as the most pressing challenges in managing the forest, which included ensuring public safety, reducing wildfire risk, or managing conflicting priorities with limited financial resources. In one case, a participant considered managing for ecosystem services to be in direct opposition to one of their largest concerns, pointing out that managing specifically for carbon would directly contradict their need to decrease forest fuel loads: "If you store carbon, it's going to burn!" More broadly, there was poor understanding of how information on ecosystem services might help address day-to-day demands and priorities of decision-makers: "It gets complicated using any type of research 
when you're actually planning stuff." Considering how an ecosystem services approach might address current management priorities should be a focus of applied research.

Throughout the interviews, it was clear that concepts such as ecosystem services can disseminate quickly through the Forest Service in the region. Some respondents noted that, while perhaps their forest had not considered ecosystem services up to this point, they had experience with the concept in a forest where they had previously worked. As planners and managers move, which appears to have happened frequently in the Pacific Northwest, new viewpoints and experiences can move with them. In some cases, it seemed that individuals who had previous experience using the ecosystem services concept were sought after for help in adapting the approach to a new context. Additionally, there was clear identification of "ecosystem services champions," people within the organization who are effective at spreading word of the concept [6]. Importantly, nearly all respondents report first hearing of the concept from some other source within the Forest Service. However, as Saarikoski et al. [6] stated, one potential problem with the application of the ecosystem services concept is that it can be employed to confirm the validity of suboptimal ways of doing things. This is a pronounced risk in the Pacific Northwest context, where there are multiple narratives regarding what ecosystem services are and what it means to manage for ecosystem services. If one particular ecosystem services workflow, that does not best leverage the available tools and methodologies, spreads in the Forest Service, there may be missed opportunities for improving outcomes. Even if clarity is established regarding definitions and conceptual frameworks, respondents perceived a large segment of their Forest Service colleagues as resistant to change. One respondent holding the Participatory Planning perspective pointed out, for example, that some districts have "fought a bit against the concept for whatever reason," not understanding "why people don't embrace the idea."

\section{Conclusions}

By employing an ecosystem services lens in the management of United States National Forests, the Forest Service hopes to connect people to the benefits national forest lands provide, addressing the shortfalls of the ecosystem-based management era as well as persistent perceptions of a continued focus on timber production [3]. However, application of the concept has been challenged by competing interpretations of what it means to manage based on ecosystem services. In Pacific Northwest National Forests, planners and managers shared a strong understanding of the basic concept of ecosystem services and considered key ecosystem services to be cultural and provisioning services most valued by local stakeholder groups (e.g., recreation, non-timber forest products), along with longstanding Forest Service priorities (e.g., terrestrial and aquatic habitat maintenance). Although respondents commonly demonstrated familiarity with the concept, there was not one clear widely adopted approach to ecosystem services-based management. Instead, three general perspectives emerged that applied elements of the concept to different degrees at different scales. Overall, participants perceived ecosystem service approaches as useful in improving consideration of local stakeholder values, broadening the array of factors considered by management beyond disciplinary objectives like meeting timber targets or managing solely for habitat, reframing the way forest benefits are communicated, and allowing managers to more intentionally weigh the benefits and tradeoffs of the management actions they consider.

While ecosystem services approaches are increasingly adapted to address specific management goals, there was little consideration of the many methodologies described in the academic literature (e.g., quantification of ecosystem services, spatial modeling, and monetary valuation). These methods were not perceived to address day-to-day information needs and were not generally acknowledged as being a core part of an ecosystem services approach. Further development of the ecosystem services concept could consider the competing needs of stakeholders at multiple scales, investigate the use of integrative modeling to quantify tradeoffs among ecosystem services by synthesizing interdisciplinary Forest Service data, better align ecosystem service approaches with a wider array of man- 
agement priorities, and clarify definitions, classifications, and workflows that disseminate throughout the Forest Service. To start, the Forest Service could fruitfully continue working with the research community to develop standardized definitions and guidance for an ecosystem services approach that would improve understanding of the wide variety of ways National Forest ecosystems affect the well-being of a large number of stakeholders and the equally numerous ways that decisions made on National Forest lands can result in tradeoffs in how ecosystem services are delivered. Future efforts toward this goal require both continued consideration of the appropriate institutional role of the Forest Service in facilitating an ecosystem services approach, the ideal scale or scales at which an ecosystem services approach should be employed, as well as the continued development of methods aimed at better understanding what ecosystem services matter to whom, why they matter, and how changes in ecosystem service delivery and its multiple impacts can be described and/or quantified.

Author Contributions: Conceptualization, S.E.C. and D.L.-C.; methodology, S.E.C., D.L.-C., and A.L.; field data collection, S.E.C.; writing—original draft preparation, S.E.C.; writing—review and editing, D.L.-C. and A.L.; funding acquisition, S.E.C., D.L.-C., and A.L. All authors have read and agreed to the published version of the manuscript.

Funding: This research was funded by a National Science Foundation Doctoral Dissertation Research Improvement award (1832315), a California State University Chancellor's Doctoral Incentive Program Mini-Grant, and the College of Arts and Letters at San Diego State University.

Institutional Review Board Statement: The study was conducted according to the guidelines of the Declaration of Helsinki and approved by the Institutional Review Board of San Diego State University (protocol code HS-2017-0137 approved 11 April 2017).

Informed Consent Statement: Informed consent was obtained from all subjects involved in the study.

Data Availability Statement: The data are not publicly available to protect the confidentiality of participants according to IRB approval obtained.

Conflicts of Interest: The authors declare no conflict of interest.

\section{References}

1. Braat, L.C.; de Groot, R. The Ecosystem Services Agenda: Bridging the Worlds of Natural Science and Economics, Conservation and Devel-Opment, and Public and Private Policy. Ecosyst. Serv. 2012, 1, 4-15. [CrossRef]

2. Costanza, R.; d'Arge, R.; de Groot, R.; Farber, S.; Grasso, M.; Hannon, B.; Limburg, K.; Naeem, S.; O’Neill, R.V.; Paruelo, J.; et al. The Value of the World's Ecosystem Services and Natural Capital. Nature 1997, 387, 253-260. [CrossRef]

3. Kline, J.D.; Mazzotta, M.J.; Spies, T.A.; Harmon, M.E. Applying the Ecosystem Services Concept to Public Land Management. Agric. Resour. Econ. Rev. 2013, 42, 139-158. [CrossRef]

4. USDA. Forest Service National Forest System Land Management Planning; USDA: Washington DC, USA, $2012 ;$ p. 115.

5. Martin-Ortega, J.; Jorda-Capdevila, D.; Glenk, K.; Holstead, K.L. What Defines Ecosystem Services-Based Approaches? In Water Ecosystem Services: A Global Perspective; Cambridge University Press: Cambridge, UK, 2015; pp. 3-14.

6. Saarikoski, H.; Primmer, E.; Saarela, S.-R.; Priess, J.A.; Aszalós, R.; Baró, F.; Baró, F.; Blanko, G.G.; Goméz-Baggethun, E.; Carvalho, L.; et al. Institutional Challenges in Putting Ecosystem Service Knowledge in Practice. Ecosyst. Serv. 2018, 29, 579-598. [CrossRef]

7. Beery, T.; Stålhammar, S.; Jönsson, K.I.; Wamsler, C.; Bramryd, T.; Brink, E.; Ekelund, N.; Johansson, M.; Palo, T.; Schubert, P. Perceptions of the Ecosystem Services Concept: Opportunities and Challenges in the Swedish Municipal Context. Ecosyst. Serv. 2016, 17, 123-130. [CrossRef]

8. Blicharska, M.; Hilding-Rydevik, T. A Thousand Flowers Are Flowering Just Now-Towards Integration of the Ecosystem Services Concept into Deci-Sion Making. Ecosyst. Serv. 2018, 30, 181-191. [CrossRef]

9. Laurans, Y.; Rankovic, A.; Billé, R.; Pirard, R.; Mermet, L. Use of Ecosystem Services Economic Valuation for Decision Making: Questioning a Literature Blindspot. J. Environ. Manag. 2013, 119, 208-219. [CrossRef]

10. Beaumont, N.J.; Mongruel, R.; Hooper, T. Practical Application of the Ecosystem Service Approach (ESA): Lessons Learned and Recommendations for the Future. Int. J. Biodivers. Sci. Ecosyst. Serv. Manag. 2017, 13, 68-78. [CrossRef]

11. Norgaard, R.B. Ecosystem Services: From Eye-Opening Metaphor to Complexity Blinder. Ecol. Econ. 2010, 69, 1219-1227. [CrossRef]

12. Bremer, L.L.; Farley, K.A.; Lopez-Carr, D. What Factors Influence Participation in Payment for Ecosystem Services Programs? an Evaluation of Ecuador's Sociopáramo Program. Land Use Policy 2014, 36, 122-133. [CrossRef] 
13. Engel, S.; Pagiola, S.; Wunder, S. Designing Payments for Environmental Services in Theory and Practice: An over-View of the Issues. Ecol. Econ. 2008, 65, 663-674. [CrossRef]

14. Farley, K.A.; Anderson, W.G.; Bremer, L.L.; Harden, C.P. Compensation for Ecosystem Services: An Evaluation of Efforts to Achieve Conservation and Development in Ecuadorian Páramo Grasslands. Environ. Conserv. 2011, 38, 393-405. [CrossRef]

15. Farley, J.; Costanza, R. Payments for Ecosystem Services: From Local to Global. Ecol. Econ. 2010, 69, 2060-2068. [CrossRef]

16. Daily, G.C.; Polasky, S.; Goldstein, J.; Kareiva, P.M.; Mooney, H.A.; Pejchar, L.; Ricketts, T.H.; Salzman, J.; Shallenberger, R. Ecosystem Services in Decision Making: Time to Deliver. Front. Ecol. Environ. 2009, 7, 21-28. [CrossRef]

17. McKenzie, E.; Posner, S.; Tillmann, P.; Bernhardt, J.R.; Howard, K.; Rosenthal, A. Understanding the Use of ECo-system Service Knowledge in Decision Making: Lessons from International Experiences of Spatial Planning. Environ. Plan. C Gov. Policy 2014, 32, 320-340. [CrossRef]

18. Nelson, E.; Mendoza, G.; Regetz, J.; Polasky, S.; Tallis, H.; Cameron, D.; Chan, K.M.; Daily, G.C.; Goldstein, J.; Kareiva, P.M.; et al. Modeling Multiple Ecosystem Services, Biodiversity Conservation, Commodity Production, and Tradeoffs at Landscape Scales. Front. Ecol. Environ. 2009, 7, 4-11. [CrossRef]

19. Costanza, R.; de Groot, R.; Braat, L.; Kubiszewski, I.; Fioramonti, L.; Sutton, P.; Farber, S.; Grasso, M. Twenty Years of Ecosystem Services: How Far Have We Come and How Far Do We Still Need to Go? Ecosyst. Serv. 2017, 28, 1-16. [CrossRef]

20. Albert, C.; Hauck, J.; Buhr, N.; Von Haaren, C. What Ecosystem Services Information Do Users Want? Investigating Interests and Requirements among Land-Scape and Regional Planners in Germany. Landsc. Ecol. 2014, 29, 1301-1313. [CrossRef]

21. Schubert, P.; Ekelund, N.G.A.; Beery, T.H.; Wamsler, C.; Jönsson, K.I.; Roth, A.; Stålhammar, S.; Bramryd, T.; Johansson, M.; Palo, T. Implementation of the Ecosystem Services Approach in Swedish Municipal Planning. J. Environ. Policy Plan. 2017, 20, $298-312$. [CrossRef]

22. Hermelingmeier, V.; Nicholas, K.A. Identifying Five Different Perspectives on the Ecosystem Services Concept Using Q Methodology. Ecol. Econ. 2017, 136, 255-265. [CrossRef]

23. Nahlik, A.M.; Kentula, M.E.; Fennessy, M.S.; Landers, D.H. Where Is the Consensus? A Proposed Foundation for Moving Ecosystem Service Concepts into Practice. Ecol. Econ. 2012, 77, 27-35. [CrossRef]

24. Hummel, C.; Provenzale, A.; Van Der Meer, J.; Wijnhoven, S.; Nolte, A.; Poursanidis, D.; Janss, G.F.; Jurek, M.; Andresen, M.; Poulin, B.; et al. Ecosystem Services in European Protected Areas: Ambiguity in the Views of Scientists and Managers? PLoS ONE 2017, 12, e0187143. [CrossRef]

25. Bremer, L.L.; Delevaux, J.M.; Leary, J.J.; Cox, L.J.; Oleson, K.L. Opportunities and Strategies to Incorporate Eco-system Services Knowledge and Decision Support Tools into Planning and Decision Making in Hawaii. Environ. Manag. 2015, 55, 884-899. [CrossRef]

26. Mascarenhas, A.; Ramos, T.B.; Haase, D.; Santos, R. Integration of Ecosystem Services in Spatial Planning: A Survey on Regional Planners' Views. Landsc. Ecol. 2014, 29, 1287-1300. [CrossRef]

27. Rinne, J.; Primmer, E. A Case Study of Ecosystem Services in Urban Planning in Finland: Benefits, Rights and Responsibilities. J. Environ. Policy Plan. 2015, 18, 1-20. [CrossRef]

28. Stepniewska, M.; Lupa, P.; Mizgajski, A. Drivers of the Ecosystem Services Approach in Poland and Perception by Practitioners. Ecosyst. Serv. 2018, 33, 59-67. [CrossRef]

29. Stevens, J.A.; Montgomery, C.A. Understanding the Compatibility of Multiple Uses on Forest Land: A Survey of Multiresource Research with AP-Plication to the Pacific Northwest. Gen. Tech. Rep. Dep. Agric. For. Serv. Pac. Northwest Res. $2002,44,539$.

30. Collins, S. Ecosystem Services: A New Perspective on Forestry. In Proceedings of the National Silviculture Workshop, Ketchikan, AK, USA, 7-10 May 2007.

31. Smith, N.; Deal, R.; Kline, J.; Blaha, D.; Patterson, T.; Spies, T.; Bennett, K. Ecosystem Services as a Framework for Forest Stewardship; US Department of Agriculture, Forest Service, Pacific Northwest Research Station: Portland, OR, USA, 2011; p. 46.

32. Kline, J.D.; Mazzotta, M.J. Evaluating Tradeoffs among Ecosystem Services in the Management of Public Lands. Eval. Tradeoffs Ecosyst. Serv. Manag. Public Lands 2012, 865. [CrossRef]

33. Olander, L.; Tallis, H.; Polasky, S.; Johnston, R.J. Best Practices for Integrating Ecosystem Services into Federal Decision Making; Duke University, National Ecosystem Services Partnership: Durham, NC, USA, 2015.

34. Asah, S.T.; Blahna, D.J.; Ryan, C.M. Involving Forest Communities in Identifying and Constructing Ecosystem Services: Millennium Assessment and Place Specificity. J. For. 2012, 110, 149-156. [CrossRef]

35. Sherrouse, B.C.; Clement, J.M.; Semmens, D.J. A GIS Application for Assessing, Mapping, and Quantifying the Social Values of Ecosystem Services. Appl. Geogr. 2011, 31, 748-760. [CrossRef]

36. Plant, R.; Ryan, P. Ecosystem Services as a Practicable Concept for Natural Resource Management: Some Lessons from Australia. Int. J. Biodivers. Sci. Ecosyst. Serv. Manag. 2012, 9, 44-53. [CrossRef]

37. USDA Forest Service Gifford Pinchot National Forest. Available online: https://www.fs.usda.gov/main/giffordpinchot/aboutforest (accessed on 7 December 2020).

38. Charnley, S. The Northwest Forest Plan-The First Ten Years (1994-2003): Socioeconomic Monitoring Results; US Department of Agriculture, Forest Service, Pacific Northwest Research Station: Portland, OR, USA, 2006.

39. USDA Forest Service Deschutes National Forest-About the Forest. Available online: https://www.fs.usda.gov/main/deschutes/ about-forest (accessed on 7 December 2020). 
40. Foley, T.; Bowles, J.; Smith, N.; Caligiuri, P. An Ecosystem Services Approach to Management of a Complex Land-scape: The Marsh Project. In Federal Resource Management and Ecosystem Services Guidebook; National Ecosystem Services Partnership, Duke University: Durham, NC, USA, 2014; pp. 1-16.

41. USDA Forest Service Fremont-Winema National Forests History. Available online: https://www.fs.usda.gov/detail/fremontwinema/about-forest/?cid=fsbdev3_061912 (accessed on 7 December 2020).

42. Hatcher, W.; Rondeau, S.; Johnson, D.L.; Johnson, K.N.; Franklin, J.F. Klamath Tribes: Managing Their Homeland Forests in Partnership with the USDA Forest Service. J. For. 2017, 115, 447-455. [CrossRef]

43. USDA. Forest Service Meet the Forest Service; USDA: Washington, DC, USA, 2018.

44. Raum, S. The Ecosystem Approach, Ecosystem Services and Established Forestry Policy Approaches in the United Kingdom. Land Use Policy 2017, 64, 282-291. [CrossRef]

45. USDA Forest Service Proposed Action for Forest Plan Revision-Nez Perce-Clearwater National Forests; Unites States Department of Agriculture Forest Service: Missoula, MT, USA, 2014; p. 139.

46. Wunder, S.; Engel, S.; Pagiola, S. Taking Stock: A Comparative Analysis of Payments for Environmental Services Programs in Developed and Developing Countries. Ecol. Econ. 2008, 65, 834-852. [CrossRef]

47. Bagstad, K.J.; Semmens, D.J.; Waage, S.; Winthrop, R. A Comparative Assessment of Decision-Support Tools for ECo-system Services Quantification and Valuation. Ecosyst. Serv. 2013, 5, 27-39. [CrossRef]

48. Bagstad, K.J.; Semmens, D.; Villa, F.; Johnson, G.; Nunes, P.; Kumar, P.; Dedeurwaerdere, T. Quantifying and Valuing Ecosystem Services: An Application of ARIES to the San Pedro River Basin, USA. Handb. Econ. Ecosyst. Serv. Biodivers. 2015, 169-192. [CrossRef]

49. Chan, K.M.A.; Guerry, A.D.; Balvanera, P.; Klain, S.; Satterfield, T.; Basurto, X.; Bostrom, A.; Chuenpagdee, R.; Gould, R.K.; Halpern, B.S.; et al. Where are Cultural and Social in Ecosystem Services? A Framework for Constructive Engagement. BioScience 2012, 62, 744-756. [CrossRef]

50. Menzel, S.; Teng, J. Ecosystem Services as a Stakeholder-Driven Concept for Conservation Science. Conserv. Biol. 2009, 24, 907-909. [CrossRef]

51. Besser, D.T.; McLain, R.; Cerveny, L.; Biedenweg, K.; Banis, D. Environmental Reviews and Case Studies: Mapping Landscape Values: Issues, Challenges and Lessons Learned from Field Work on the Olympic Peninsula, Washington. Environ. Pr. 2014, 16, 138-150. [CrossRef] 